\title{
Patterns of pay: results of the Annual Survey of Hours and Earnings 1997 to 2010
}

Ryan Pike

Office for National Statistics

\section{Summary}

The Annual Survey of Hours and Earnings is the most detailed and comprehensive source of information on levels of earnings, make-up of total earnings and the distribution of earnings of individual employees. This article presents summary analyses from the results of the 2010 ASHE, comparing them with the 2009 results and where relevant the 1997 to 2009 back series. Of particular interest are the variations in earnings between different industries, occupations, regions and age groups and how these variations have changed over time.

\section{Key points}

- In April 2010 median gross weekly earnings were $£ 499$ (for full-time UK employee jobs on adult rates whose earnings were not affected by absence), up 2.1 per cent from $£ 488$ in 2009.

- Between 2009 and 2010 the weekly earnings for full-time employees in the bottom decile grew by 2.0 per cent to $£ 276$, compared with growth of 1.3 per cent in the top decile to $£ 984$.

- For the 2009/10 tax year median gross annual earnings for full-time employees on adult rates who have been in the same job for at least 12 months were $£ 25,900$. For males, median gross annual earnings were $£ 28,100$ while the comparable figure for females was $£ 22,500$.

- In April 2010 median hourly earnings excluding overtime for full-time employees were $£ 12.50$, up 1.4 per cent from $£ 12.33$ in 2009 . Women's hourly earnings were $£ 11.68$ while the comparable figure for men was $£ 13.01$.

- The stronger growth in women's hourly earnings excluding overtime compared with men's (2.6 per cent compared with 0.3 per cent) meant that the gender pay gap for full-time employees narrowed to 10.2 per cent in 2010, from 12.2 per cent in 2009. 


\section{Introduction}

The Annual Survey of Hours and Earnings (ASHE) is ONS's most detailed and comprehensive source of information on:

- levels of earnings (for both full-time and part-time employees and for gender)

- make-up of total earnings (split between basic pay and other components)

- distribution of earnings (the extent to which earnings are dispersed around the median)

ASHE focuses on estimates of the median rather than the mean. The median is the value below which fifty per cent of employees fall. The median is preferred to the mean for earnings as it is less affected by extreme values and the skewed distribution of earnings data. However, estimates of the mean are still available in the annually published results.

More details on the methodology for the survey can be found at www.statistics.gov.uk/cci/article. asp? $\mathrm{id}=985$.

The first few sections of this article present summary analyses on overall medians, the make-up of earnings, the distribution of earnings and gender pay differences for the 2010 ASHE, comparing the analysis with the 2009 results (and, where relevant, with the 1997 to 2009 back series). While these estimates are of interest, they can hide wide variations between different industries, occupations, regions and age groups. The concluding sections of the article give summary analyses of each of these breakdowns and the corresponding gender pay differences.

Tables containing the figures referenced within this article can be found on the National Statistics website at: www.statistics.gov.uk/StatBase/Product.asp?vlnk=14123.

\section{Summary results for full-time employees}

Median gross weekly earnings for full-time employees on adult rates of pay working a full week in April 2010 were $£ 499$ (see Figure 1). At $£ 538$, median gross weekly earnings for men increased by 1.3 per cent over the year. This is compared with a 3.1 per cent rise for women to $£ 439$. Since 1997 median gross weekly earnings for women working full-time have increased significantly more than for men (66 per cent for women compared with 51 per cent for men).

Median gross annual earnings of all full-time employees on adult rates who have been in the same job for at least a year were $£ 25,900$ for the $2009 / 10$ tax year. For men, median gross annual earnings were $£ 28,100$, down 0.6 per cent from 2009 , while the figure for women was $£ 22,500$, up 1.7 per cent. 
Median hourly earnings, excluding overtime, of all full-time employees were $£ 12.50$ in April 2010, an increase of 1.4 per cent since April 2009. Female employees working full-time saw an increase of 2.6 per cent in hourly earnings excluding overtime, compared with 0.3 per cent for men.

\section{Figure 1 Median gross weekly earnings of full-time employees by gender, 1997 to $2010^{*}$}

$£$ per week

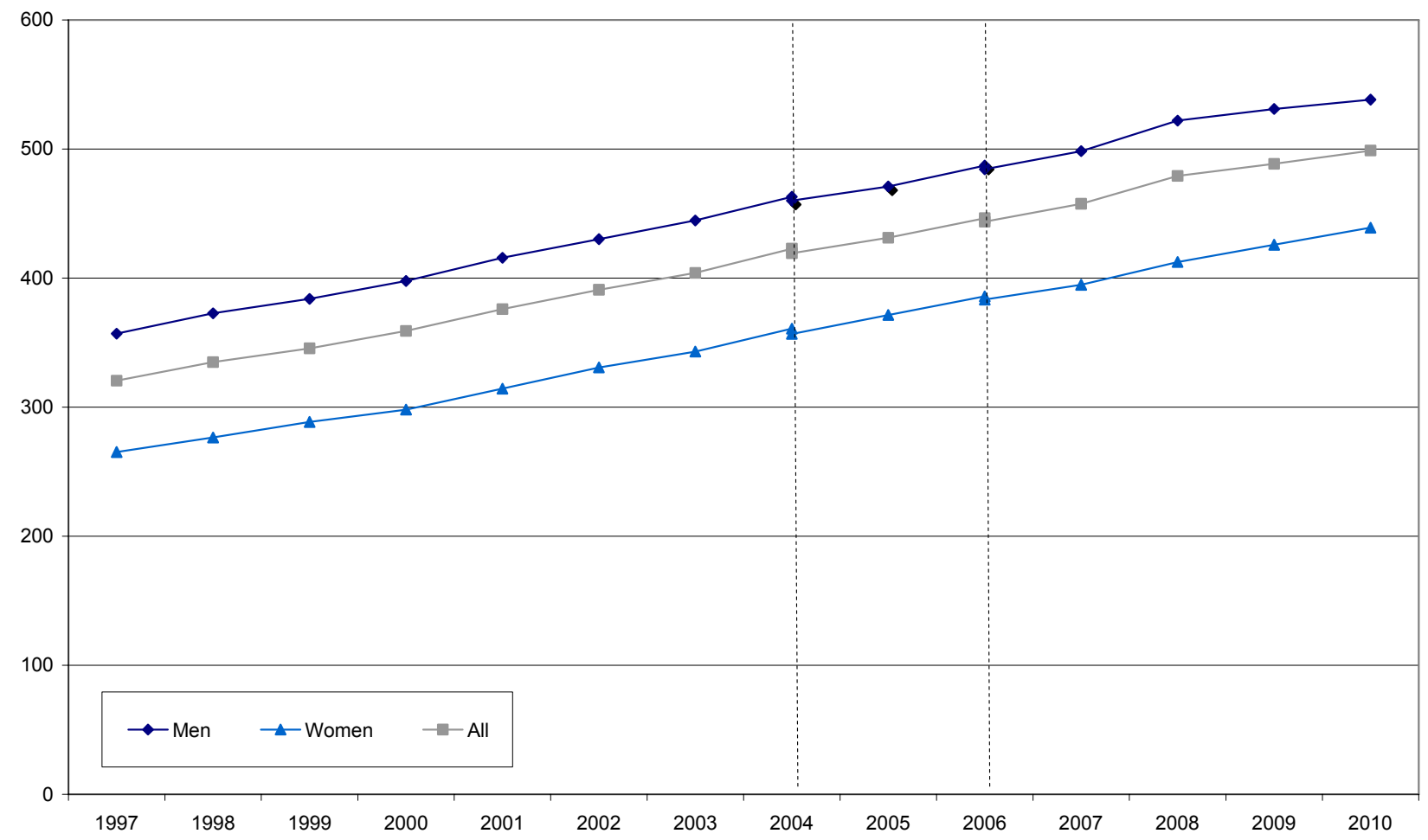

* Employees on adult rates, pay unaffected by absence

Broken vertical lines represent discontinuities in 2004 and 2006 ASHE results. These changes are detailed in the technical notes at the end of the article.

Source: Annual Survey of Hours and Earnings, Office for National Statistics

Since 1997 there has been a slight fall in the mean total paid hours worked per week by full-time employees (39.2 hours in 2010 compared with 40.0 hours in 1997). In April 2010 men worked 40.4 paid hours per week and women worked 37.4 paid hours per week.

\section{Summary results for part-time employees}

Part-time employees work 30 hours per week or less, or, for those in teaching professions, less than 25 hours per week. They earned a median hourly rate, excluding overtime of $£ 7.97$ in April 2010, an increase of 2.1 per cent over the year. For men the increase was 0.3 per cent over the year to $£ 7.69$, while for women the increase was 1.8 per cent to $£ 8.00$. Since 1997 , female 
employee hourly rates have remained above the levels for male employees (see Figure 2) with little change to the pay gap during this period.

\section{Figure 2 Median hourly earnings, excluding overtime, of part-time employees by gender, 1997 to 2010 *}

$£$ per hour

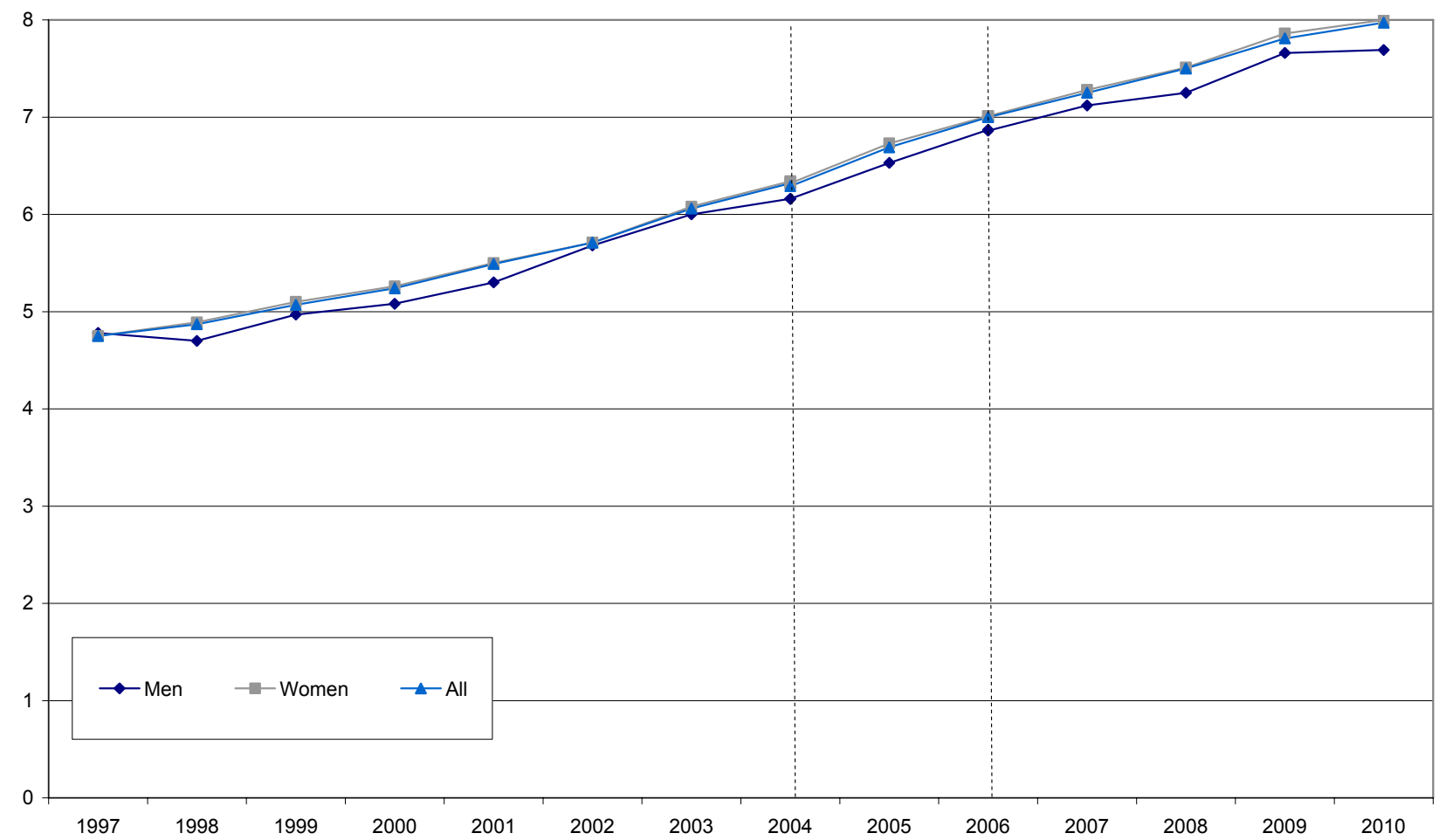

* Employees on adult rates, pay unaffected by absence

Broken vertical lines represent discontinuities in 2004 and 2006 ASHE results. These changes are detailed in the technical notes at the end of the article.

Source: Annual Survey of Hours and Earnings, Office for National Statistics

There has been a slight increase in the ratio of part-time to full-time median hourly earnings excluding overtime since 1997. In 2010 median hourly earnings excluding overtime for part-time workers were 63.8 per cent of those for full-time workers (compared with 60.6 per cent in 1997). For men, part-time earnings were 59.1 per cent of full-time earnings (compared with 56.8 per cent in 1997) and for women the comparable figures were 68.5 per cent in 2010 and 68.4 per cent in 1997 (see Figure 3). 


\section{Figure 3 Ratio of part-time to full-time median hourly earnings, 1997 to 2010 *}

Per cent

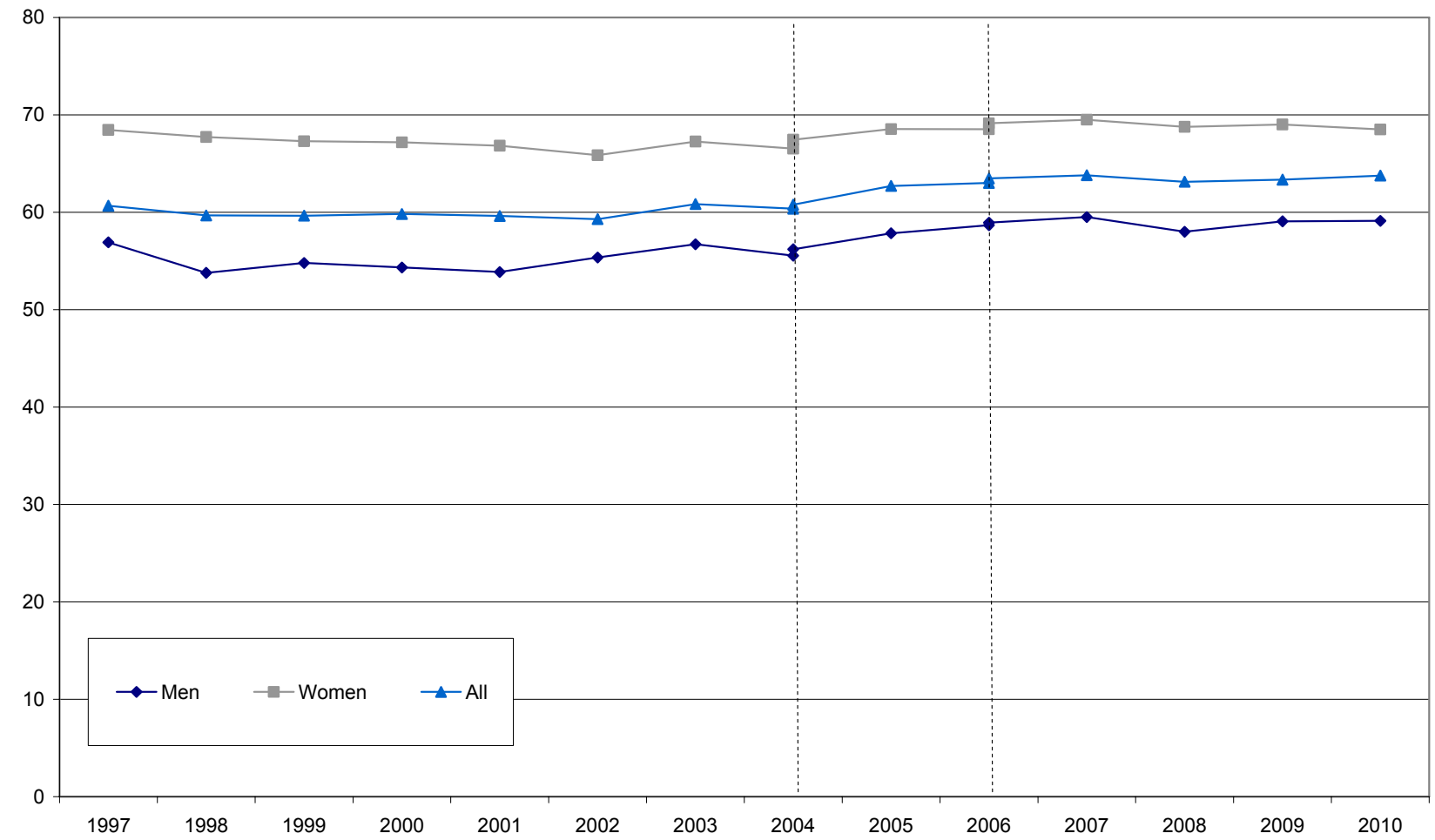

${ }^{*}$ Hourly earnings excluding overtime. Employees on adult rates, pay unaffected by absence

Broken vertical lines represent discontinuities in 2004 and 2006 ASHE results. These changes are detailed in the technical notes at the end of the article.

Source: Annual Survey of Hours and Earnings, Office for National Statistics

The proportion of male employees in the total workforce who worked part-time rose from 4.2 per cent to 5.9 per cent between 1997 and 2010. However, this figure is still well below the proportion of female employees working part-time, which fell from 21.2 per cent to 20.8 per cent of the total workforce over the same period. (Note that these figures are based on Labour Force Survey (LFS) estimates of the composition of the employee workforce for the period April to June 2010).

Median hourly pay for female employees working part-time is higher than that of male employees, partly due to a higher proportion of females working part-time throughout their careers. Figure 4 shows the distribution of part-time employees by gender and by age. This shows that a higher proportion of females work part-time in the higher income age groups (aged 30 to 39, 40 to 49 and 50 to 59). The proportion of males working part-time is higher in the younger age groups as well as the 60 and over age group. 


\section{Figure 4 Distribution of part-time employees by gender and age- group, April 2010*}

Per cent

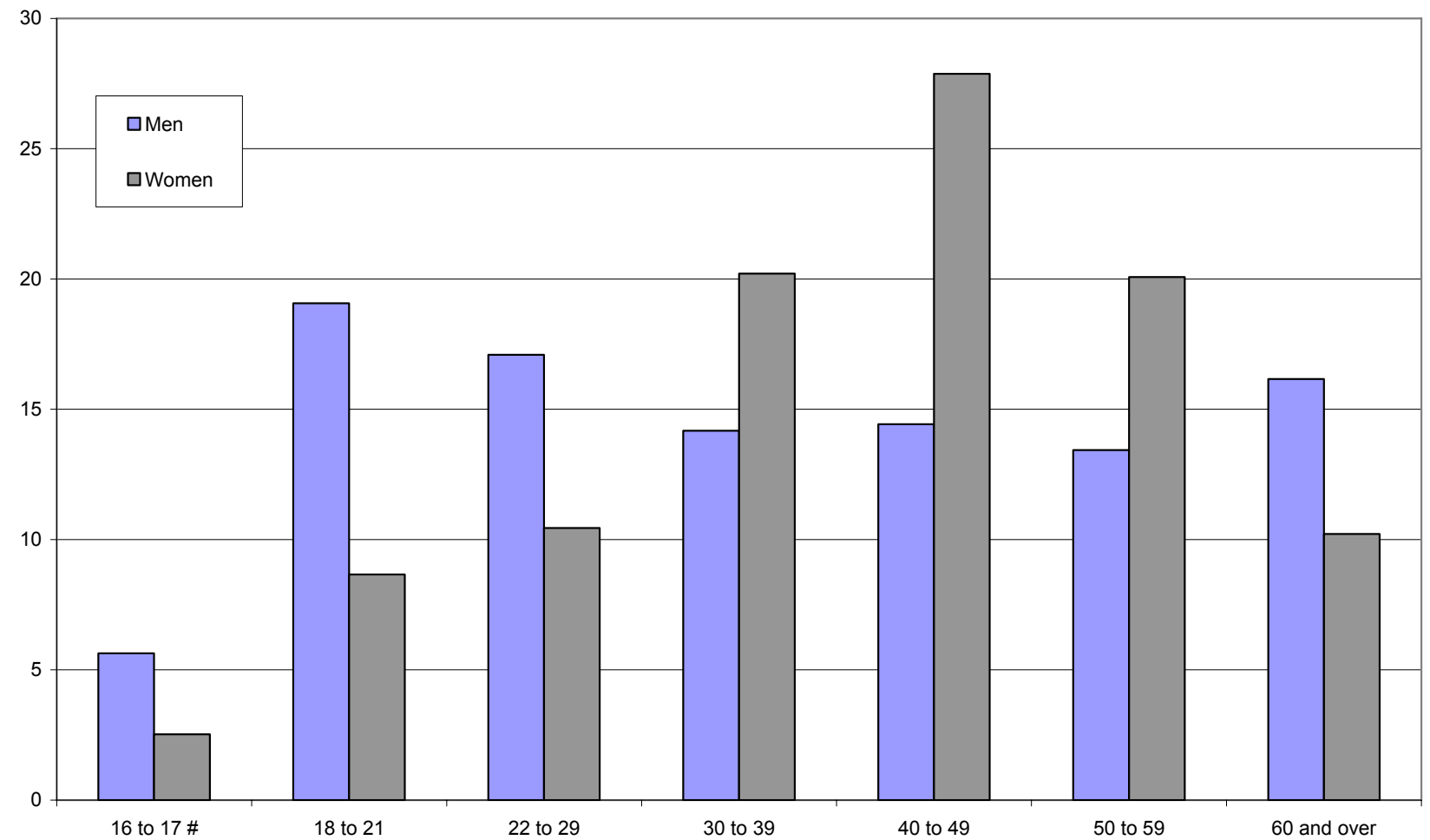

* Employees on adult rates, pay unaffected by absence

\# Results for 16 to 17 year-olds include employees not on adult rates of pay

Source: Annual Survey of Hours and Earnings, Office for National Statistics

\section{Pay differences between men and women}

In 2009 ONS reviewed the way it presents gender pay statistics. The review concluded that there was no single measure which adequately dealt with the complex issue of the differences in men's and women's pay. ONS now highlights the following measures:

- female full-time employees' median pay compared with male full-time employees' median pay

- female part-time employees' median pay compared with male part-time employees' median pay

- all female employees' median pay compared with all male employees' median pay

ONS prefers to use hourly earnings, excluding overtime, and focuses on estimates of the median. Including overtime can skew the results because men work relatively more overtime than women. 
For full-time employees, hourly earnings excluding overtime were $£ 11.68$ for women (on adult rates whose pay for the pay period was unaffected by absence) and $£ 13.01$ for men. This has resulted in the gender pay gap narrowing in 2010 to 10.2 per cent, down from 12.2 per cent in 2009 (see Figure 5). The gender pay gap has therefore fallen by around seven percentage points (from 17.4 per cent) for full-time employees in the thirteen years since 1997.

Median hourly earnings for women working part-time are higher than those of part-time men. Men's hourly earnings were $£ 7.69$, up 0.3 per cent from $£ 7.66$ in 2009 , compared with women's hourly earnings of $£ 8.00$, an increase of 1.8 per cent from $£ 7.86$ in the previous year. The negative gender pay difference for part-time employees has therefore widened to minus 4.0 per cent from minus 2.5 per cent in 2009.

The gender pay difference for all employees decreased to 19.8 per cent from 22.0 per cent in 2009, a narrowing of around eight percentage points (from 27.5 per cent) since 1997.

\section{Figure 5 Pay gap between women's and men's median hourly earnings, 1997 to $2010^{*}$}

Per cent

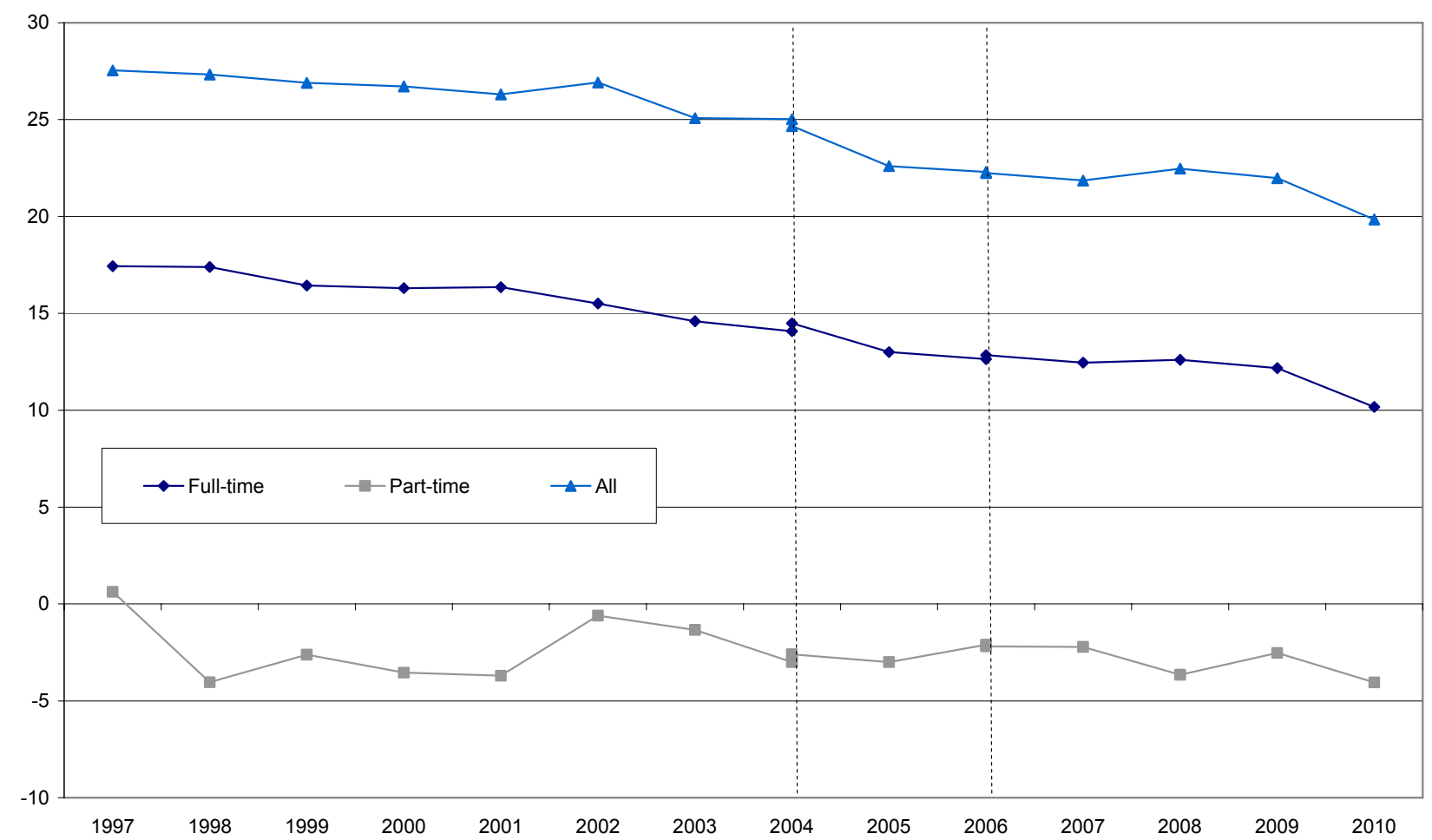

* Hourly earnings excluding overtime. Employees on adult rates, pay unaffected by absence

Broken vertical lines represent discontinuities in 2004 and 2006 ASHE results. These changes are detailed in the technical notes at the end of the article.

Source: Annual Survey of Hours and Earnings, Office for National Statistics 
Although ONS's headline estimates of gender pay differences are based on median hourly earnings, mean hourly earnings provide a useful supplementary measure. The differences between median and mean gender pay gaps reflect the extent to which high earners skew the earnings distribution.

The gender pay difference for mean full-time hourly earnings is wider than that for median earnings and has fallen from 20.7 per cent to 15.5 per cent since 1997 (see Figure 6). Men's mean hourly earnings were $£ 16.25$, up 1.1 per cent from $£ 16.07$ in 2009 . Women's mean hourly earnings increased by 2.2 per cent from $£ 13.44$ in 2009 to $£ 13.73$ in 2010 . The mean gender pay difference of 15.5 per cent for full-time employees was at its narrowest in 2010 since the series was introduced in 1997.

In contrast with the median measure, mean hourly earnings for part-time employees were lower for women than for men. Nevertheless, the gender pay gap based on mean hourly earnings decreased slightly, to 11.7 per cent, down from 11.8 per cent in 2009.

The gender pay difference based on the mean for all employees also decreased in 2010 to 19.3 per cent from 20.1 per cent in the previous year.

\section{Figure $6 \quad$ Pay gap between women's and men's mean hourly earnings, 1997 to $2010^{*}$}

Per cent

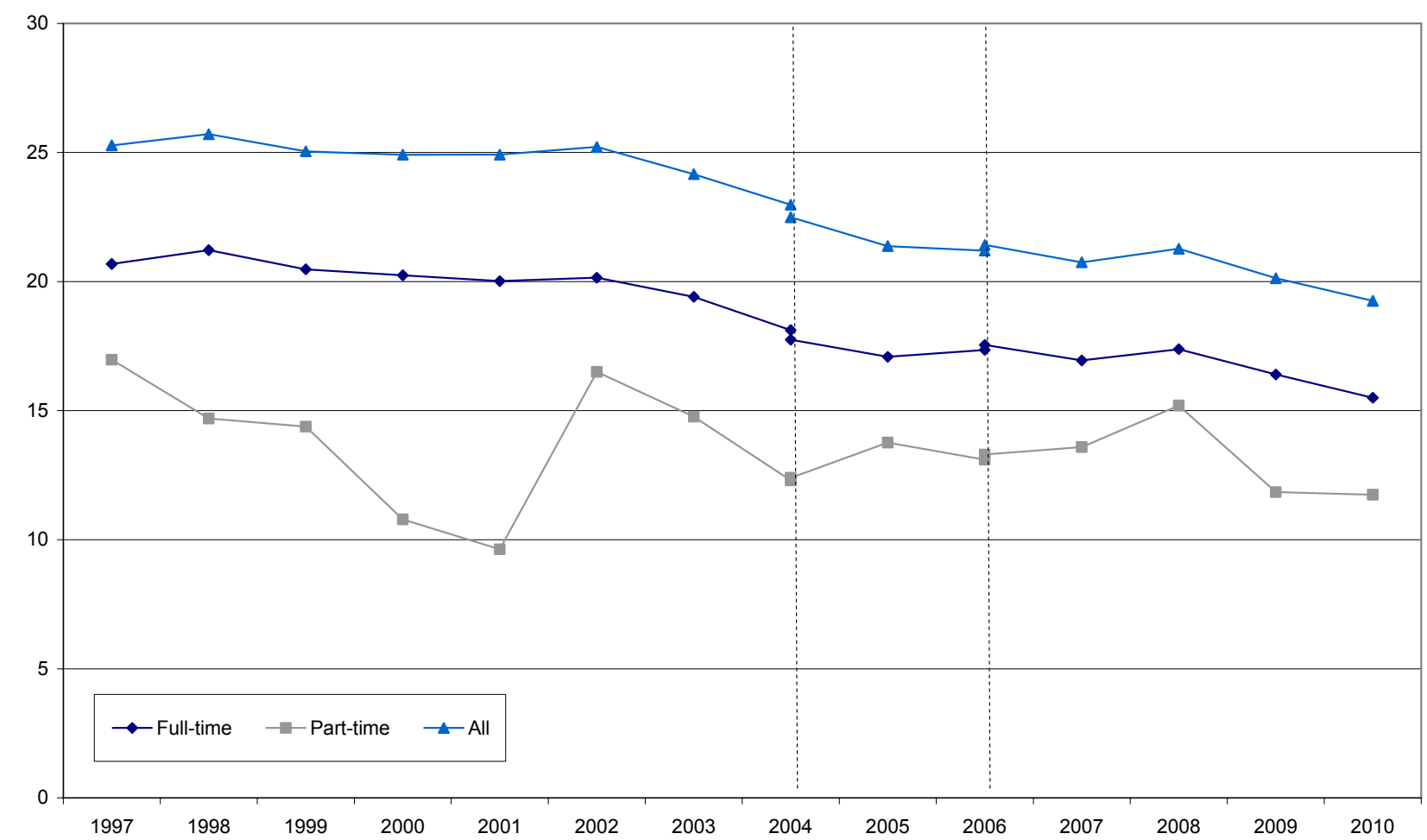

* Hourly earnings excluding overtime. Employees on adult rates, pay unaffected by absence

Broken vertical lines represent discontinuities in 2004 and 2006 ASHE results. These changes are detailed in the technical notes at the end of the article.

Source: Annual Survey of Hours and Earnings, Office for National Statistics 
Although median and mean hourly pay provide a useful comparison of men's and women's earnings, they do not reveal differences in rates of pay for comparable jobs. This is because such measures do not highlight the different employment characteristics of men and women, such as the proportion of each gender in different occupations and their length of time in jobs. In addition, it is noteworthy that the gender pay gap is relatively small for employees in the 16 to 39 age groups, and grows substantially thereafter. This may reflect some women taking time out of the labour market in order to have children, thereby missing pay increases and opportunities for promotion that might otherwise have been available. Figure 6 illustrates the variation in the gender pay gap across the age-groups.

\section{The make-up of earnings}

ASHE splits gross weekly earnings into four components: overtime payments, payments by results/incentive payments ${ }^{1}$ (such as bonuses and so on), premium payments for shift work, and the residual - which includes basic pay and allowances. The first three components vary quite considerably by type of worker.

The proportion of additional payments of mean gross weekly earnings for male employees working full-time was higher than that of their female counterparts over the period 1997 to 2010 . In 2010 male employees earned $£ 43$ additional payments, which accounted for 6.6 per cent of their total pay, whereas women's additional payments $(£ 16)$ accounted for just 3.2 per cent of their total pay.

In 2010 mean overtime payments for full-time employees were $£ 17.50$ per week, up from $£ 16.40$ in 2009. Mean payments by results/incentive payments increased from $£ 8.30$ in 2009 to $£ 9.00$ in 2010. The 2009 figure was the lowest since the introduction of this measurement in 2000.

Shift premium payments were $£ 6.20$ in 2010 , up from $£ 6.00$ in the previous year. Historically, shift premium payments have fluctuated between $£ 5.40$ and $£ 6.10$ since 2000 .

\section{The distribution of earnings}

Figure 7 displays the distribution of gross weekly earnings among full-time employees for the years 1997 to 2010 . The median level of gross full-time weekly earnings in 2010 was $£ 499$ per week. This is lower than the mean (£598) since the latter is boosted by the relatively few people at the top end of the distribution with extremely high earnings. For 2010, at the bottom of the distribution, a tenth of full-time employees earned less than $£ 276$ per week, whereas at the other end of the scale a tenth earned more than $£ 984$ per week. The ratio of the highest to the lowest decile for gross weekly earnings (3.6 in April 2010) gives a measure of the distribution of weekly pay. This ratio has been very stable since 1997, when it was 3.5 . 


\section{Figure 7 Distribution of gross weekly earnings for full-time employees, 1997 to 2010 *}

$£$ per week

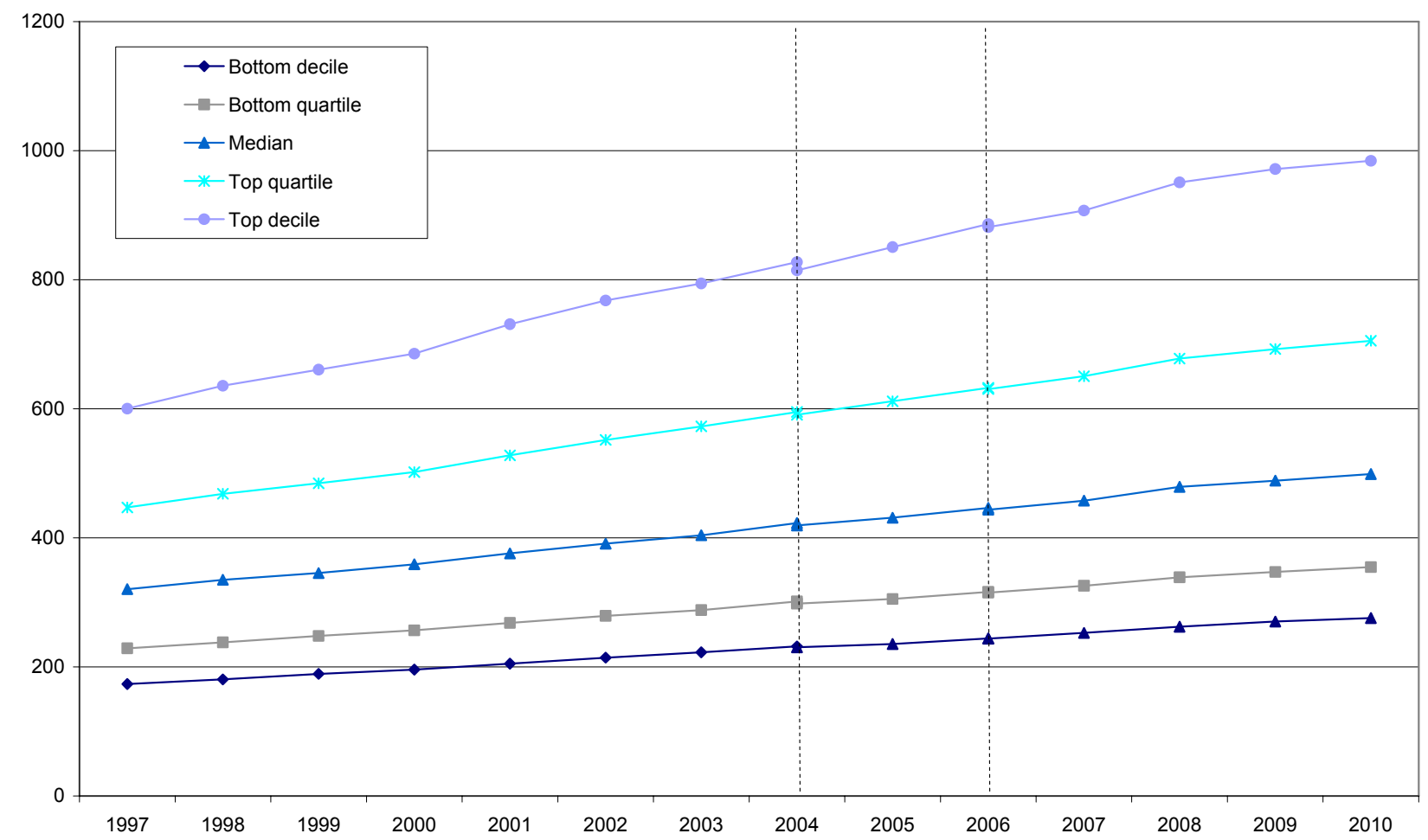

* Employees on adult rates, pay unaffected by absence

Broken vertical lines represent discontinuities in 2004 and 2006 ASHE results. These changes are detailed in the technical notes at the end of the article.

Source: Annual Survey of Hours and Earnings, Office for National Statistics

In the year to April 2010 median gross weekly earnings of full-time employees in the bottom decile of the distribution grew faster than those in the top decile (2.0 per cent against 1.3 per cent respectively). Between 1998, the year before the introduction of the National Minimum Wage, and 2010, the top decile increased by 54.8 per cent against a bottom decile increase of 52.7 per cent.

Figure 8 shows the patterns of growth in the top and bottom deciles of gross weekly earnings for full-time employees and for the Retail Prices Index (RPI) since 1997. The RPI is the most familiar general purpose domestic measure of inflation in the UK. Between April 2009 and April 2010 the growth in earnings for the top and bottom deciles slowed. The RPI conversely, saw a dramatic shift, moving from a decrease of 1.2 per cent to an increase of 5.3 per cent. This is only the second time that growth in the RPI has increased above the rate of growth in the top and bottom deciles of the earnings distribution since 1997. 


\section{Figure $8 \quad$ Earnings growth in top and bottom deciles for full-time employees and changes in RPI, 1997 to 2010*}

Per cent

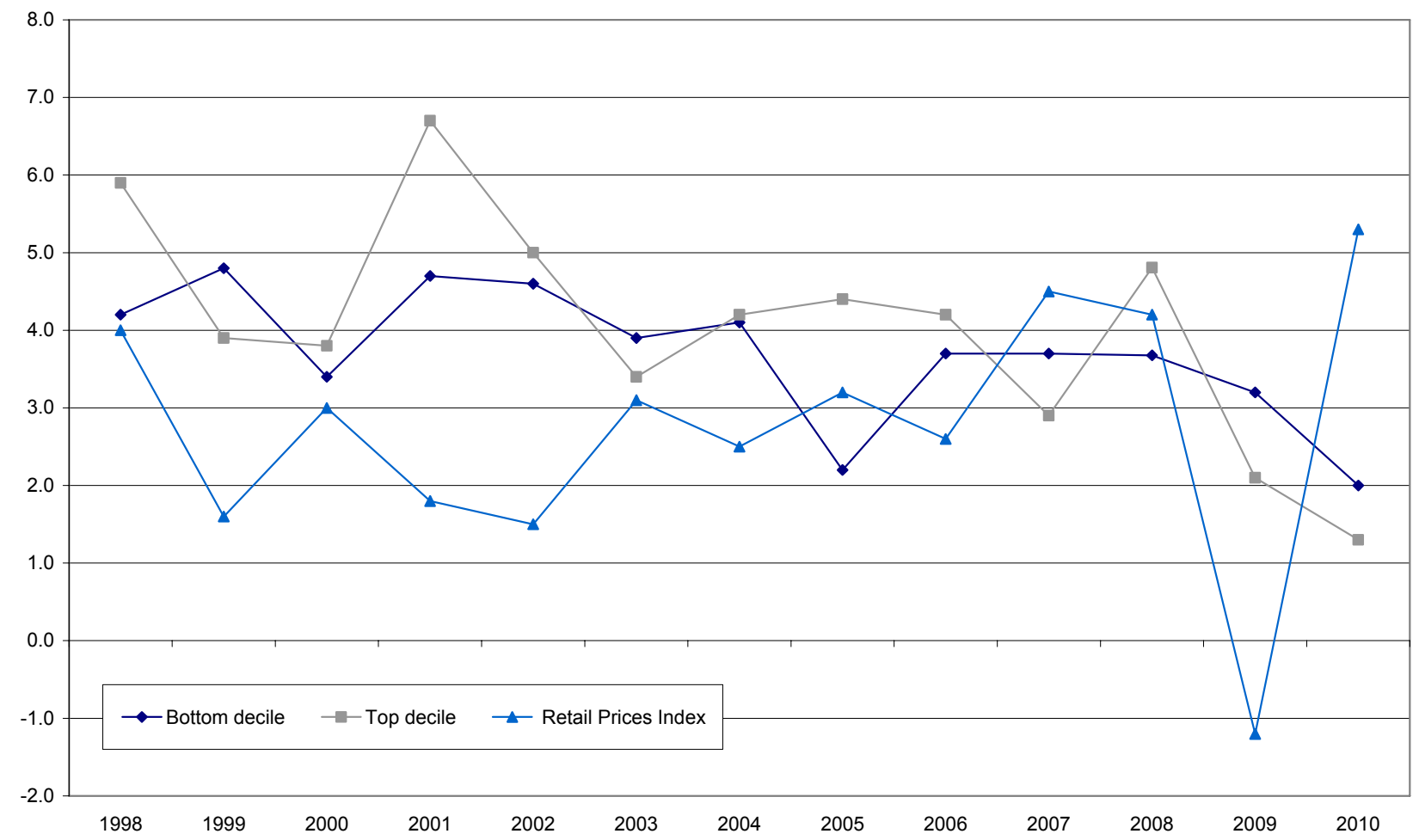

Source: Annual Survey of Hours and Earnings, Office for National Statistics

\section{Results by industry}

For ASHE, the Standard Industrial Classification (SIC) 2007 has replaced the Standard Industrial Classification (SIC) 2003 as the classification used to present earnings statistics. The first year available on the new basis is 2008. From 2009 onwards the figures are presented on the SIC 2007 basis only.

Median gross weekly earnings for full-time employees in April 2010 were highest in the mining and quarrying sector at $£ 709$ (see Figure 9). This was $£ 57$ per week more than the second highest, the information and communication sector. Weekly earnings in the mining and quarrying sector are boosted by longer paid hours worked by employees relative to other sectors. Over the period 1997 to 2010 financial and insurance activities has also featured as one of the highest median gross weekly earnings sectors. The accommodation and food service activities sector has the lowest median gross weekly earnings. At $£ 304$, full-time employees' earnings were some $£ 90$ per week lower than the median for the wholesale and retail sector (the second lowest paid). 


\section{Figure $9 \quad$ Median gross weekly earnings by industry, April 2010}

$£$ per week

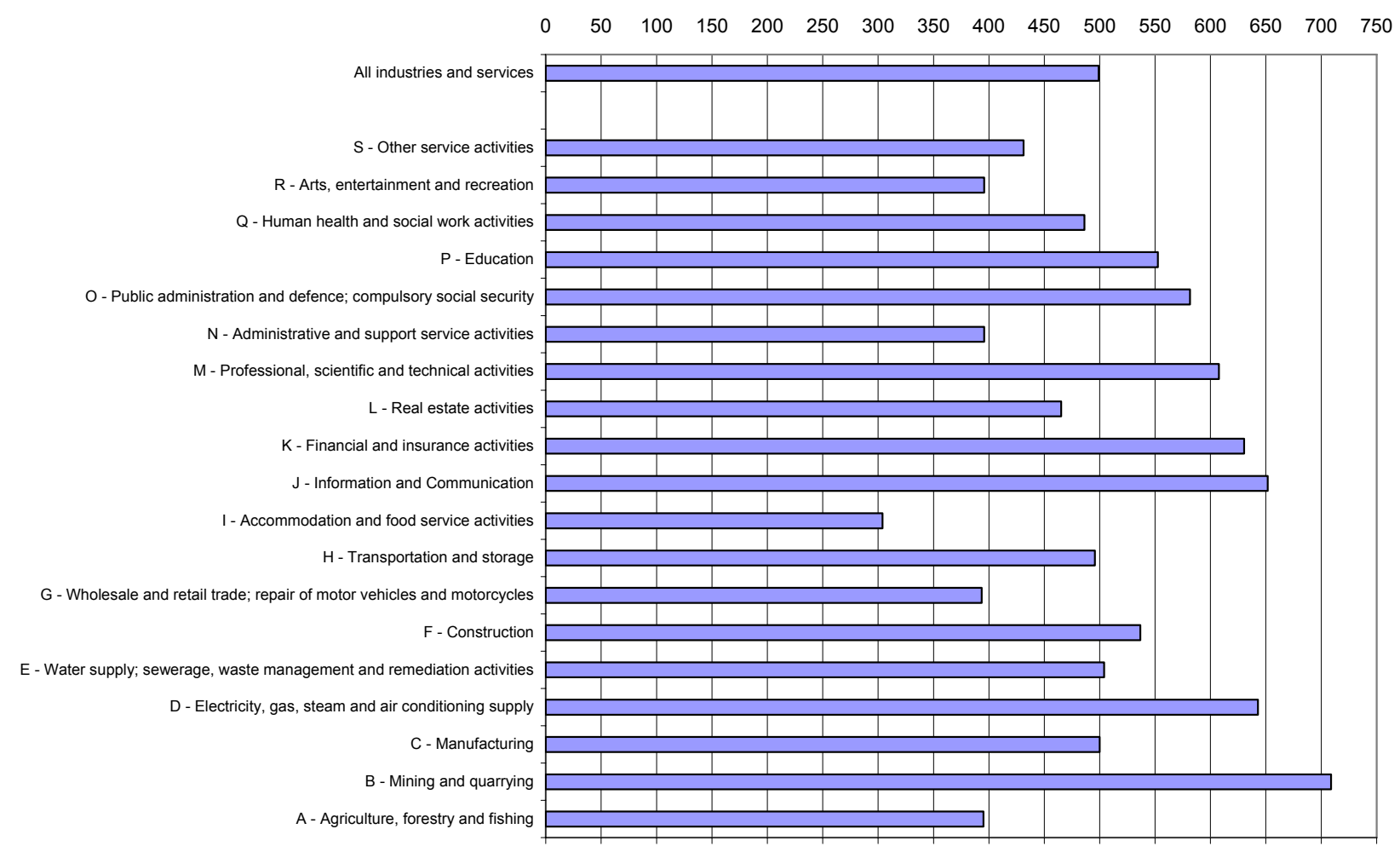

* Full-time employees on adult rates, pay unaffected by absence. Figures based on SIC 2007

Source: Annual Survey of Hours and Earnings, Office for National Statistics

Median full-time gross annual earnings of $£ 36,100$ in the mining and quarrying sector were more than double that of the accommodation and food service activities sector, which was the lowest paid with earnings of $£ 15,900$. The picture changes, however, when we consider mean gross annual earnings, rather than median. On this measure, the highest-earning sector is the financial and insurance activities sector, with mean annual earnings of $£ 56,000$. The next highest sector is mining and quarrying at $£ 47,900$. The difference between median and mean earnings reflects the skewed nature of the earnings distribution, with high earners exerting a disproportionate pull on mean figures.

The financial and insurance activities sector had the highest median hourly earnings excluding overtime for full-time employees (£17.41), followed by the information and communication sector (£16.78). At the bottom of the scale, median hourly earnings excluding overtime for the accommodation and food service activities sector were $£ 7.23$.

The broad industrial groupings described above can hide substantial variation within the sectors. ASHE, however, allows more detailed industrial analyses. For example, it is possible to identify the highest and lowest paid industry divisions (two-digit Standard Industrial Classification (SIC) 2007). Such analyses reveal that two of the top five divisions come from manufacturing, the tenth highestearning sector as a whole. These are the manufacture of coke and refined petroleum ( $£ 889$ per week) and the manufacture of tobacco products ( $£ 761$ per week). Food and beverage service activities was the lowest paid division of all, at $£ 300$ per week. 
For full-time employees, the largest gender pay difference (based on median hourly earnings excluding overtime) was for the financial and insurance activities sector at 39 per cent. For parttime employees the gender pay difference varies considerably between the sectors. For example, even though the overall gender pay difference is negative, many of the broad industrial sectors have positive gender pay differences, the largest of which is in Education at 35 per cent. For all employees, regardless of whether they worked full-time or part-time, the gender pay gap was highest in the financial and insurance activities sector at 42 per cent.

\section{Public and private sector earnings}

The difference between private and public sector median earnings for full-time employees increased between April 2009 and April 2010. Private sector median gross weekly earnings were $£ 473$, up 2.0 per cent from 2009. Public sector earnings were $£ 554$, up 3.0 per cent (see Figure $10)$. Public sector mean gross weekly earnings ( $£ 622$ ) were also higher than those of the private sector (£589).

\section{Figure 10 Median gross weekly earnings for full-time employees by public/private sector, 1997 to 2010 *}

$£$ per week

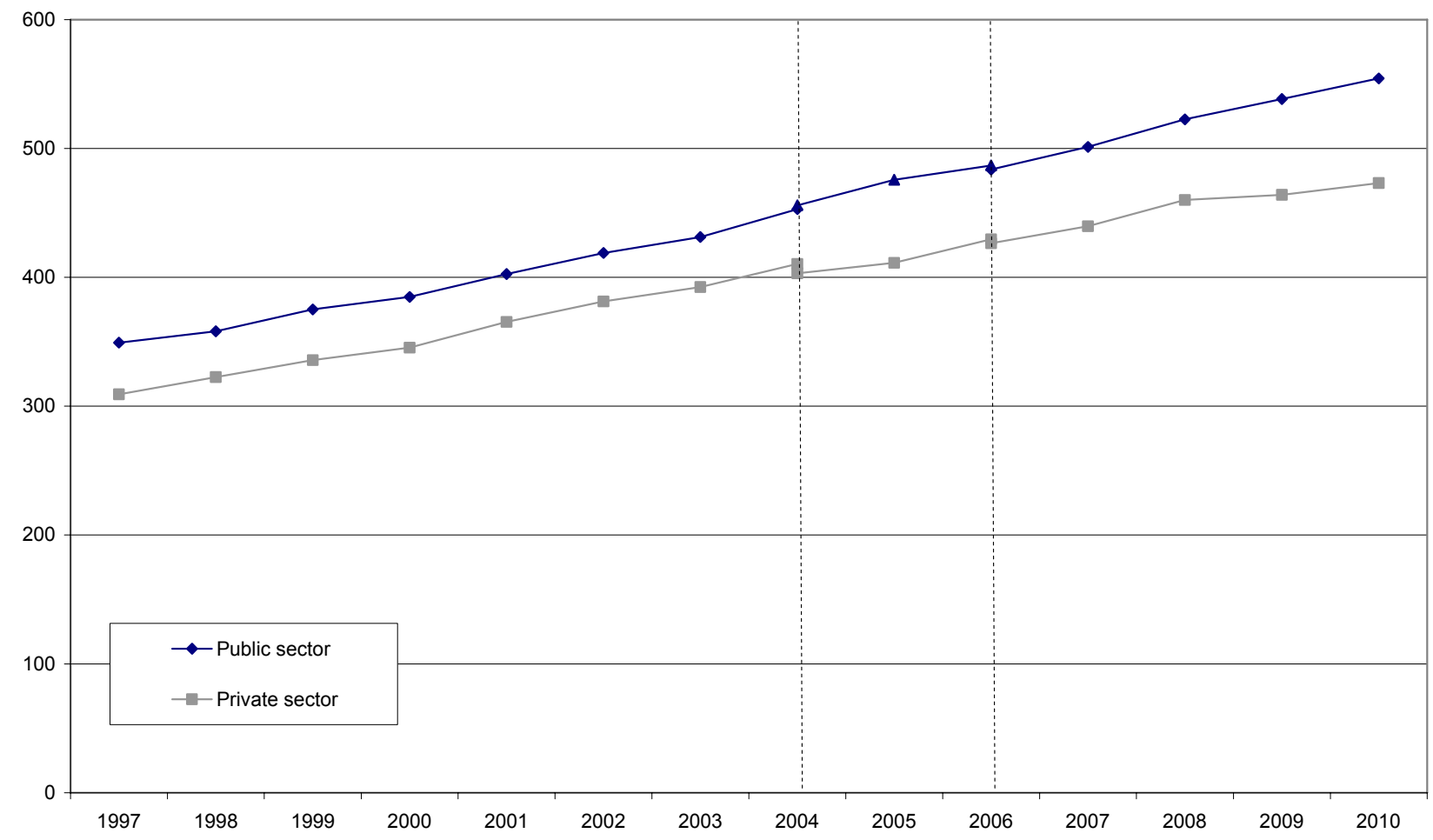

* Employees on adult rates, pay unaffected by absence

Broken vertical lines represent discontinuities in 2004 and 2006 ASHE results. These changes are detailed in the technical notes at the end of the article.

Source: Annual Survey of Hours and Earnings, Office for National Statistics 
ASHE breakdowns by public and private sector are produced according to the legal status of the employers. Between 2008 and 2009 Lloyds Banking Group, the Royal Bank of Scotland Group and HBOS PLC were reclassified from the private sector to the public sector. This means that care must be taken when interpreting public / private sector movements through this period. It is expected that the UK governments' shares in these banks will eventually be sold and at that time they will be re-classified to the private sector.

As with gender pay comparisons, differences in gross weekly earnings do not reveal differences in rates of pay for comparable jobs. This is due to differences in the composition of the public and private sectors. For example, many of the lowest paid occupations, such as bar and restaurant staff, hairdressers, elementary sales occupations and cashiers, exist primarily in the private sector, while there are a larger proportion of graduate-level and professional occupations in the public sector ${ }^{2}$.

\section{Figure 11 Pay gap between women's and men's hourly earnings by public/private sector, April 2010*}

Per cent

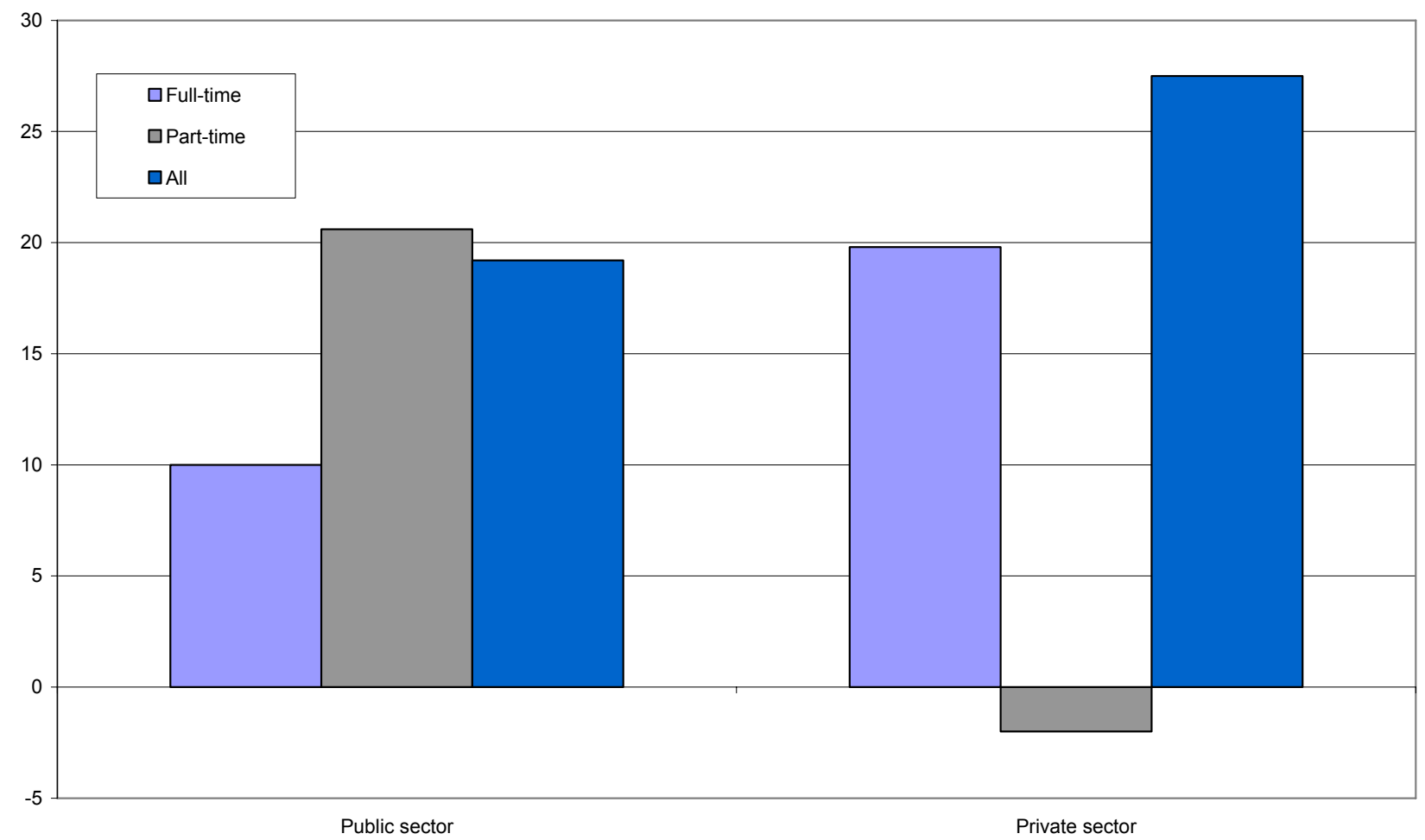

* Hourly earnings excluding overtime. Employees on adult rates, pay unaffected by absence

Source: Annual Survey of Hours and Earnings, Office for National Statistics

Gender pay differences vary between the public and private sectors, depending on whether the employee is in full-time or part-time employment (see Figure 11). For full-time employees the gender pay gap in the public sector is 10.0 per cent. The comparable figure for the private sector is 19.8 per cent. For part-time employees, the gender pay differences in the public and private 
sectors are 20.6 per cent and minus 2.0 per cent respectively. Gender pay differences for all employees (regardless of whether they are full-time or part-time) are 19.2 per cent in the public sector and 27.5 per cent in the private sector.

\section{Results by occupation}

ASHE 2010 data for occupation is coded to Standard Occupation Classification (SOC) 2000 which was introduced in 2002. Before then SOC 1990 was used.

The occupational major group (as defined within SOC 2000) with the highest median gross weekly earnings for full-time employees was managers and senior officials at $£ 722$ (see Figure 12). Sales and customer service occupations were, as for the years since the introduction of SOC 2000, the lowest paid median gross weekly major group at $£ 303$ per week for full-time employees. This major group includes occupations that are generally acknowledged to be low-paid such as retail cashiers and check-out operators, and market and street traders and assistants. In April 2010 the highest increase was in process plant and machine operatives occupations (2.7 per cent). The lowest increase was in professional occupations, at 1.1 per cent.

\section{Figure 12 Median gross weekly earnings by occupation, April 2010*}

$£$ per week

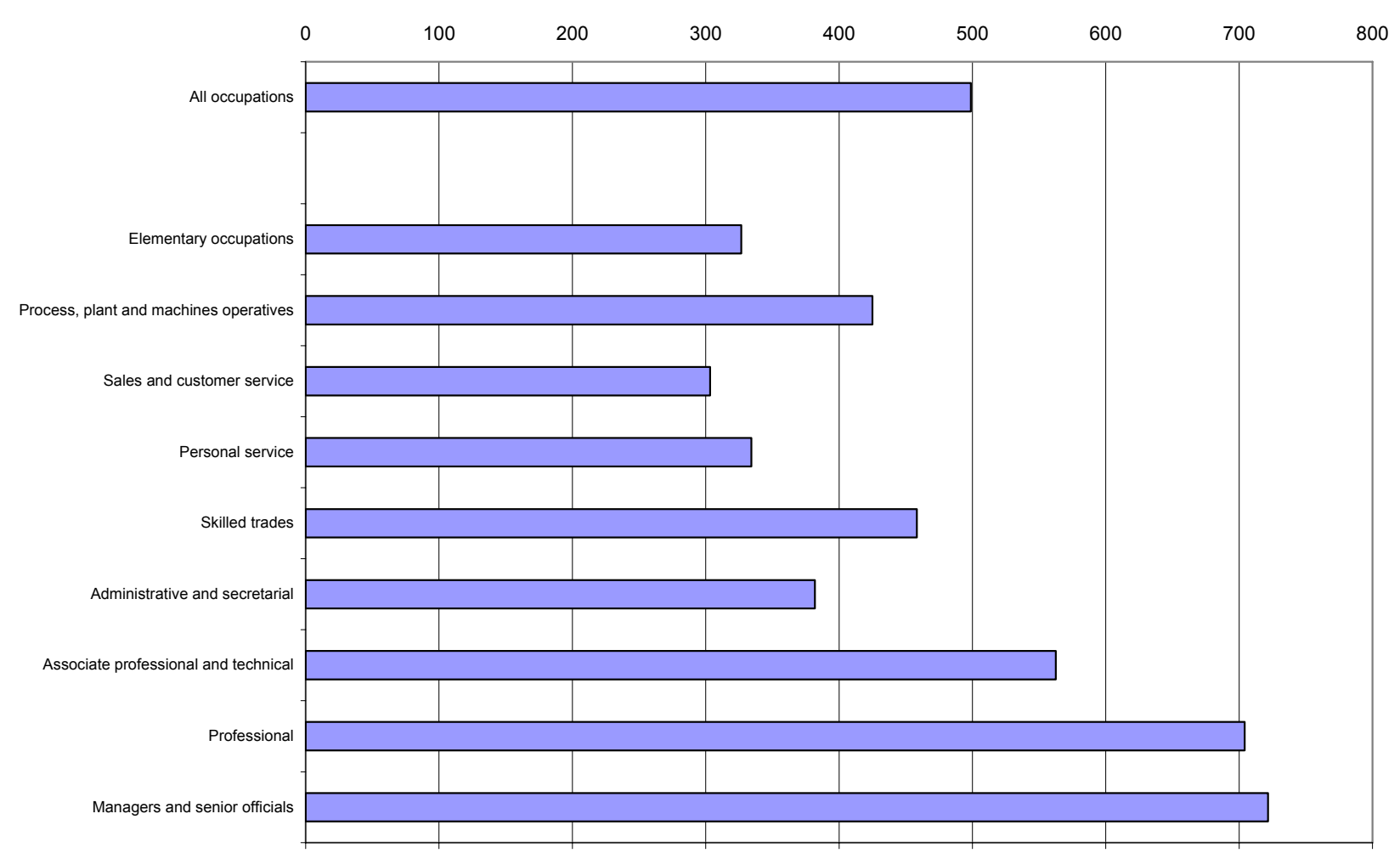

* Full-time employees on adult rates, pay unaffected by absence

Source: Annual Survey of Hours and Earnings, Office for National Statistics 
The highest median gross annual earnings for full-time employees were in the managers and senior officials group $(£ 37,800)$ and professional occupations $(£ 36,500)$. The lowest annual earnings were in sales and customer service occupations, at $£ 15,600$.

Managers and senior officials have had the highest annual and weekly full-time earnings for eight of the nine years since SOC 2000 was introduced. However, hourly earnings excluding overtime have been highest in the professional occupations for all of this time. This is explained by the fact that managers and senior officials are paid for more hours of work and receive larger annual incentive payments than employees in professional occupations. Annual earnings for managers and senior officials have typically been 2 to 4 per cent higher than those of professional occupations, while their weekly earnings have typically been 0 to 2 per cent higher. Conversely, hourly earnings for professional employees have been 4 to 9 per cent higher than those of managers and senior officials. In 2010 professional employees' full-time median hourly earnings were $£ 19.70$, and managers and senior officials' were $£ 18.92$.

In 2010 the highest paid unit group occupation (four-digit Standard Occupation Classification 2000) for full-time employees was directors and chief executives of major organisations, with median gross weekly earnings of $£ 1,744$. This represents a decrease of 4.8 per cent on the 2009 figure. The next highest paid occupation was aircraft pilots and flight engineers with median gross weekly earnings of $£ 1,316$ per week. At $£ 245$ per week, bar staff were the lowest paid of all full-time employees on adult rates of pay, followed by waiters and waitresses at $£ 250$.

With median hourly earnings excluding overtime of $£ 38.22$, medical practitioners were the highest paid part-time employees for whom estimates were available. The lowest, at $£ 5.80$, were waiters and waitresses, bar staff and upholsterers. $£ 5.80$ was the national minimum wage for those aged 22 and over in April 2010.

Figure 13 shows the median gender pay differences for 2010 broken down by the Standard Occupation Classification (SOC) 2000 major occupation groups for full-time employees. The median gender pay gap for full-time employees was narrowest for professional occupations (4.2 per cent) and widest for skilled trades occupations (26.0 per cent).

For part-time employees there are large variations in the gender pay gap. The median gender pay gap is widest for managers and senior officials (18.7 per cent), though this is not as wide as it is for full-time employees in the same occupation group. The gender pay differences for associate professional and technical occupations, administrative and secretarial occupations, personal service occupations and elementary occupations are negative (-12.5 per cent, -3.0 per cent, -2.3 per cent and -0.8 per cent respectively) meaning that part-time women earn more than part-time men in these occupations.

For all employees, regardless of whether they work on a full-time or part-time basis, the gender pay difference is, again, widest for skilled trades occupations (31.4 per cent). The narrowest gap, as with full-time employees, is for professional occupations at 1.6 per cent. 


\section{Figure 13 Pay gap between women's and men's median hourly earnings by occupation, April 2010*}

Per cent

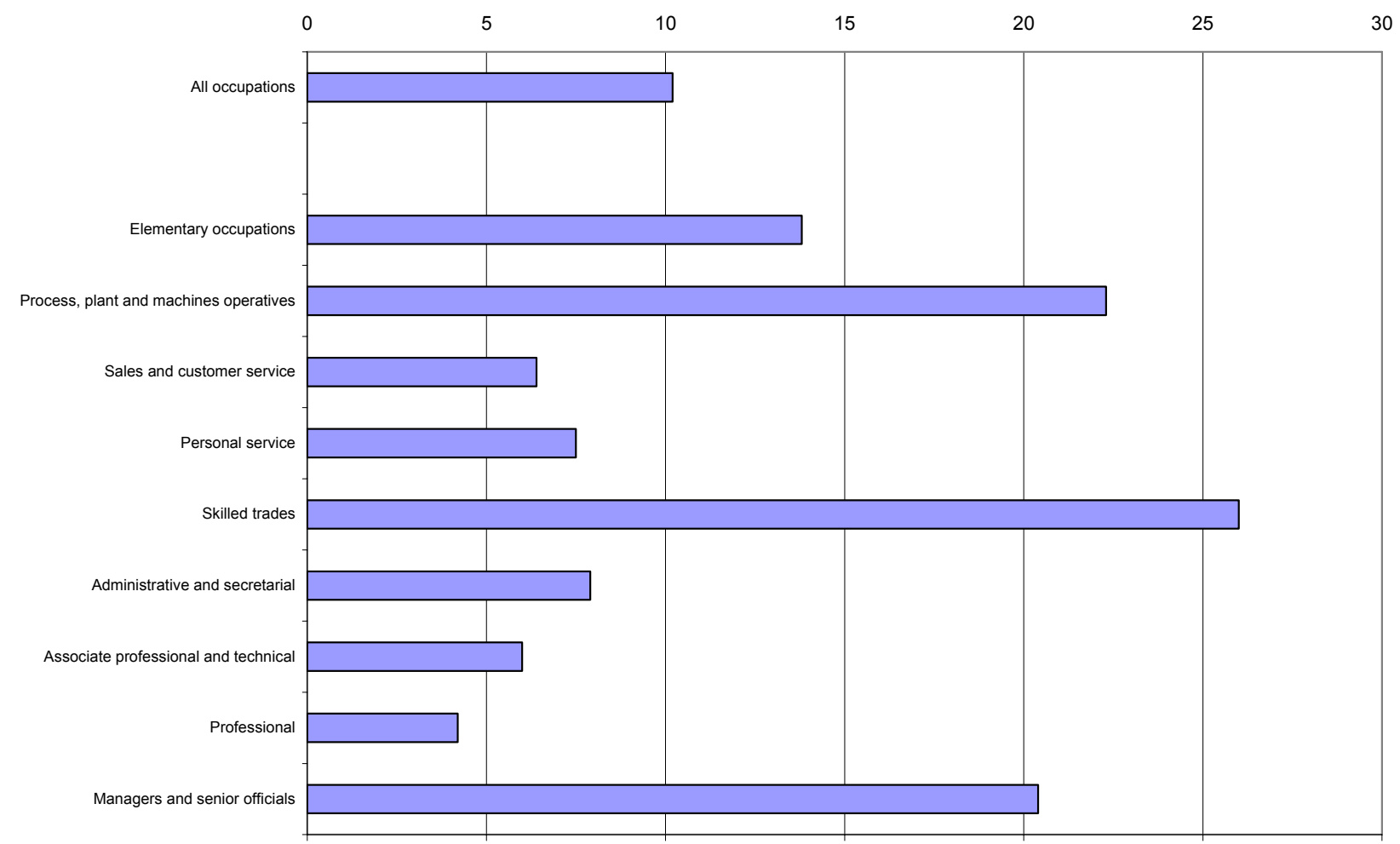

* Full-time employees on adult rates, pay unaffected by absence

Source: Annual Survey of Hours and Earnings, Office for National Statistics

\section{Results by region}

At $£ 642$, London tops the regional list for median gross weekly earnings for full-time employees in April 2010. This was more than one hundred pounds above the next highest, the South East (£524). London’s high levels of pay are largely due to the fact that a high proportion of its labour force is employed in high-paying industries and occupations, and also because many employees are entitled to allowances for working in the capital. Northern Ireland (£441) was at the bottom of the regional list with the North East (at £442) and Wales (at £451) completing the bottom three. The figure for the whole of the UK was $£ 499$.

The largest increase since 2009 was seen in Scotland, where weekly earnings rose by 3.3 per cent to $£ 488$. The smallest increase was in Northern Ireland ( 0.8 per cent), which follows an increase in 2009 of 4.7 per cent, the second largest increase in that year.

Since 1997 similar patterns were observed for median gross annual pay and median hourly pay excluding overtime, with London topping the list followed by the South East. The North East, Wales and Northern Ireland have the lowest pay levels across the regions. In Yorkshire and the Humber, the East Midlands, the West Midlands, the East of England, the South West and Northern Ireland, 
median gross annual earnings for full-time employees were less than they were in 2009. Northern Ireland was the only region to see a fall in full-time hourly earnings, down by one penny to $£ 10.85$.

It should be noted that earnings comparisons take no account of variations in prices for goods and services between regions and therefore do not necessarily indicate differences in the standard of living. Neither do they take account of differences in the regional composition of the workforce, meaning that like-for-like comparisons may not be appropriate. For example, a region might have a lower level of median earnings than another if it has a higher proportion of employees in industries or occupations with relatively low earnings.

In the UK, the gender pay gap was 10.2 per cent. The largest gender pay gap was 16.8 per cent in the South East region. In Northern Ireland there was a negative pay gap of minus 0.1 per cent. Over the period 1997 to 2010 the largest fall in the gender pay difference was in Northern Ireland (from 16.5 per cent to minus 0.1 per cent) and the smallest was in London (15.1 per cent to 12.5 per cent). Figure 14 illustrates changes in the gender pay gap for the four home countries.

\section{Figure 14 Pay gap between women's and men's earnings by country, 1997 to 2010 *}

Per cent

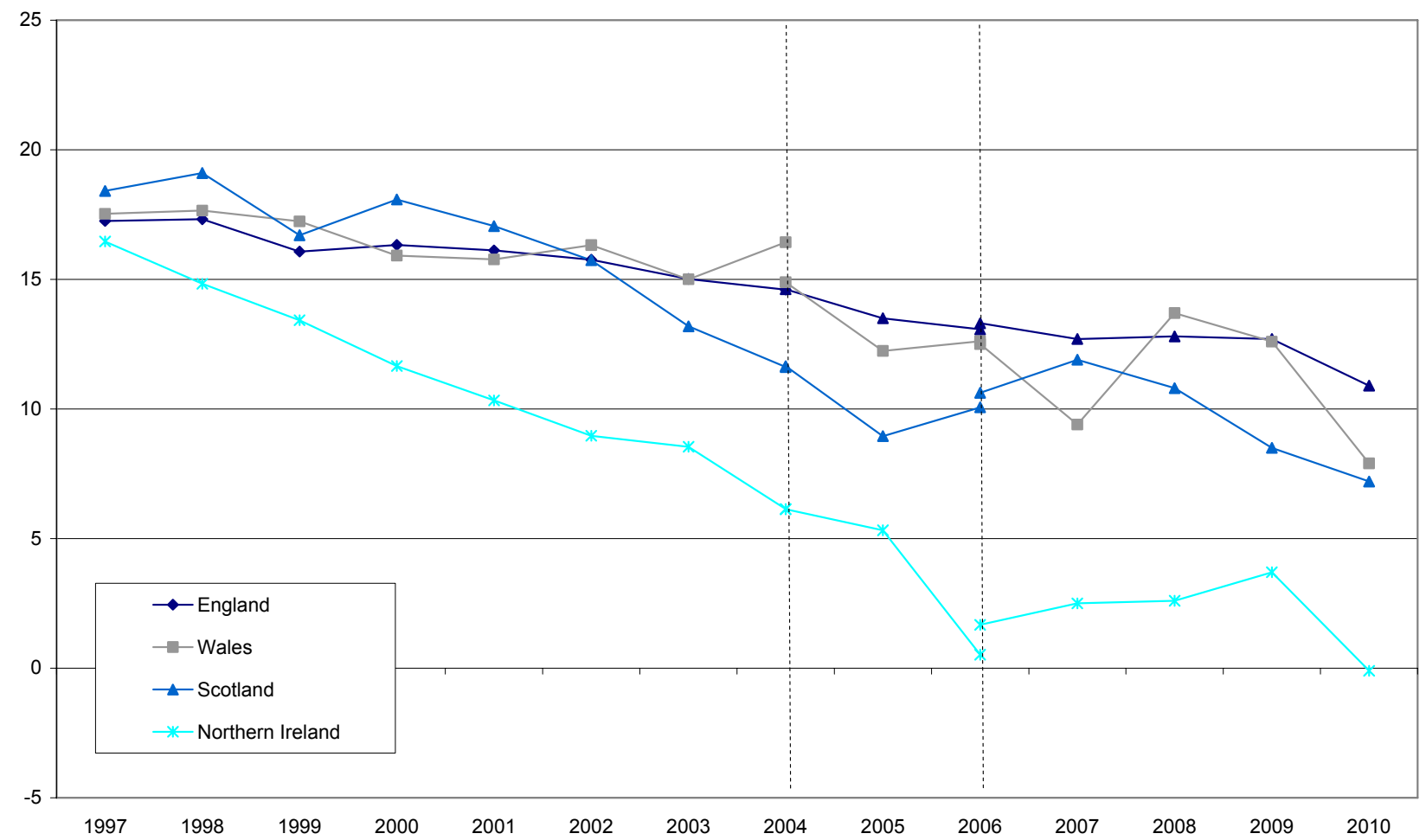

* Full-time employees on adult rates, pay unaffected by absence. Figures based on hourly earnings excluding overtime. Broken vertical lines represent discontinuities in 2004 and 2006 ASHE results. These changes are detailed in the technical notes at the end of the article.

Source: Annual Survey of Hours and Earnings, Office for National Statistics 


\section{Results by age group}

Median gross weekly earnings for full-time employees climb steadily with age, reaching a maximum in the 40-49 age-group ( $£ 560$ ), and declining thereafter. Women's earnings peak earlier than those of men, reaching a high in the 30-39 age-group. This pattern is continuous over the period 1997 to 2010 . Women's full-time weekly earnings climbed with age to reach a maximum of $£ 508$ for those aged 30 to 39. Men's full-time earnings reached their highest of $£ 614$ for those aged 40 to 49 (see Figure 15).

\section{Figure 15 Median gross weekly earnings by gender and age group, April 2010*}

$£$ per week

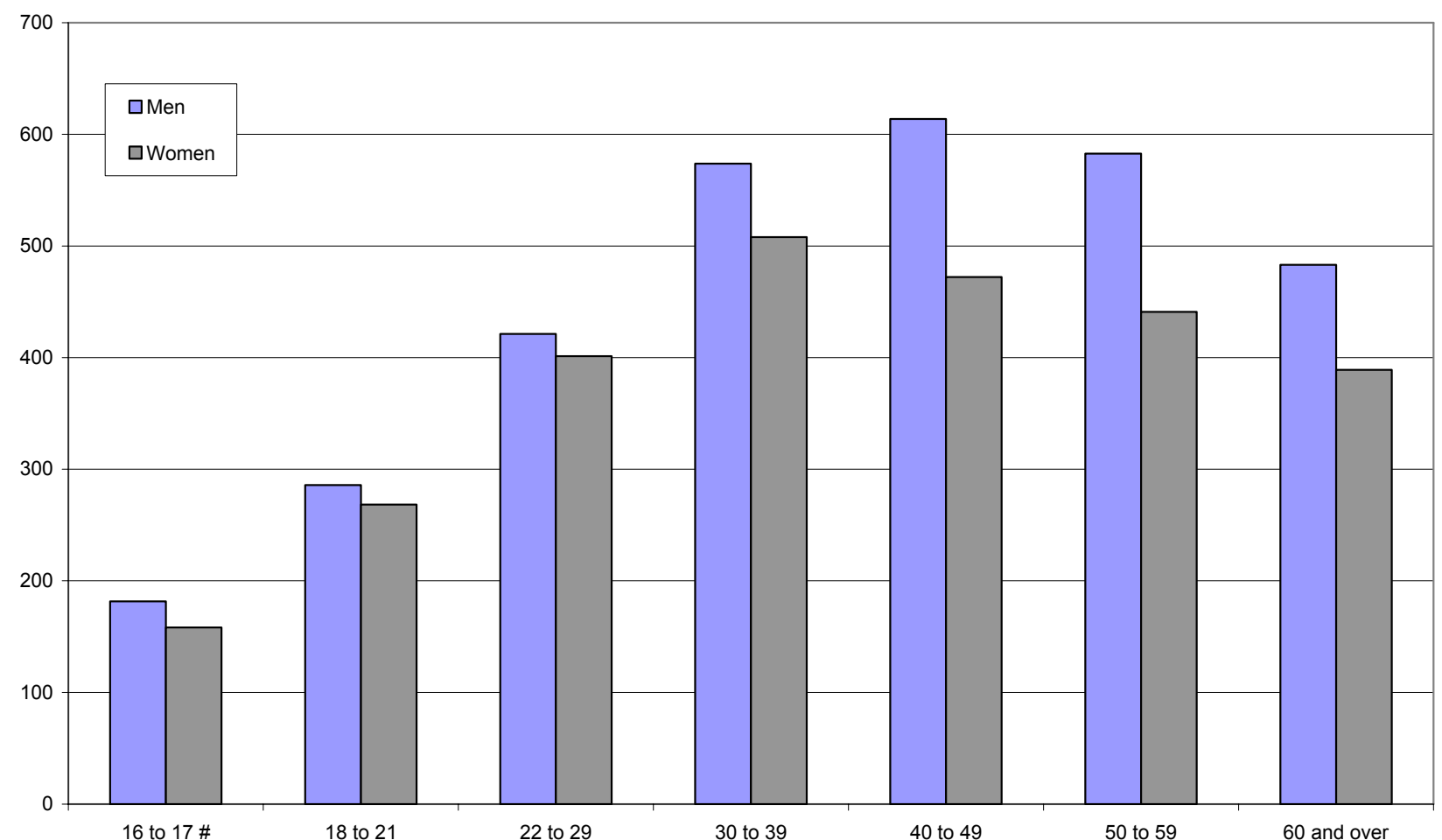

* Full-time employees on adult rates, pay unaffected by absence

\# Results for 16 to 17 year-olds include employees not on adult rates of pay

Source: Annual Survey of Hours and Earnings, Office for National Statistics

The largest increase in median gross weekly earnings between April 2009 and April 2010 was recorded for full-time employees aged 50 to 59 , an increase of 2.8 per cent to $£ 528$. There was a slight fall in the median earnings of 18 to 21 year-olds which decreased by 0.1 per cent to $£ 277$.

Figure 16 shows median gender pay differences by age group. The pay gap, based on hourly earnings excluding overtime, is relatively small for the younger age-groups, ranging from minus 2.1 per cent for 22 to 29 year-olds to 2.9 per cent for 30 to 39 year-olds. The gap then increases 
dramatically for the 40 to 49 age-group (16.1 per cent), peaks in the 50 to 59 year olds (17.0 per cent) and tails off somewhat for those aged 60 and over.

\section{Figure 16 Pay gap between women's and men's median hourly earnings by age, April 2010*}

Per cent

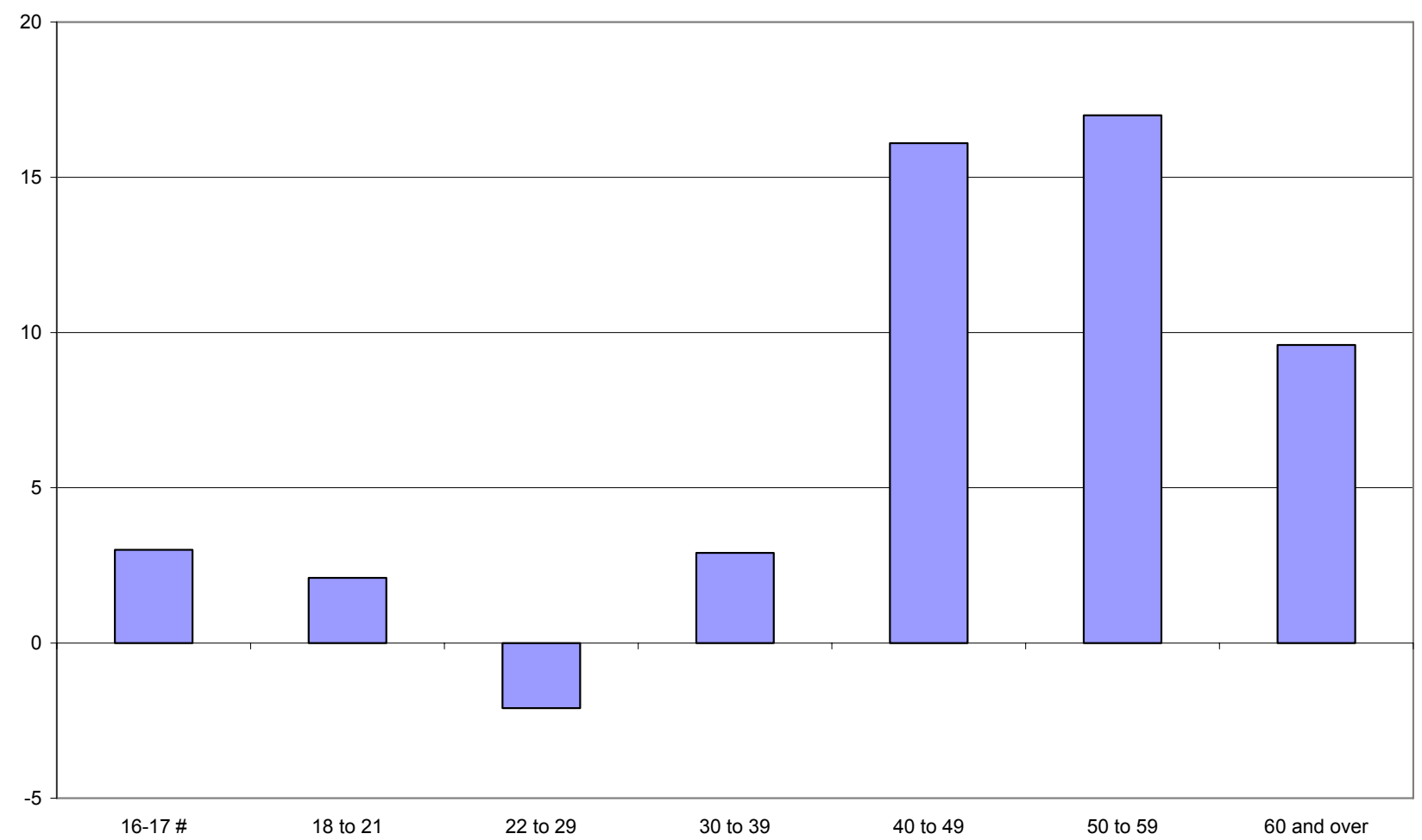

* Full-time employees on adult rates, pay unaffected by absence

\# Results for 16 to 17 year-olds include employees not on adult rates of pay

Source: Annual Survey of Hours and Earnings, Office for National Statistics

Gender pay differences for part-time employees and all employees (regardless of whether they work on a full-time or part-time basis) show a similar pattern to the full-time pay gap, with relatively small differences for young age-groups and high differences for older age-groups.

\section{Comparisons with the Average Weekly Earnings indicator}

Each month ONS also collects information on earnings from the Monthly Wages and Salaries Survey, used to construct the Average Weekly Earnings (AWE) series. This survey asks 9,000 employers to provide information about total pay and numbers of employees, but does not collect more detailed information on the occupational and demographic characteristics of their employees. The AWE is ONS's lead measure of changes in the level of earnings, having replaced the Average Earnings Index (AEI) in the Labour Market Statistical Bulletin from January 2010 onwards.

The AWE and ASHE are not directly comparable on all measures of earnings. The closest measure that can be derived and compared for these surveys is for mean gross weekly pay. In the 
year to April 2010 the ASHE estimate of mean gross weekly pay for all employees (regardless of whether they were full-time or part-time) was $£ 488$, up 1.4 per cent on the previous year. The comparable estimate from the AWE was $£ 446$, up 0.4 per cent from April 2009. For the private sector, the ASHE estimate of mean gross weekly pay for all employees was $£ 485$, while the AWE estimate was $£ 443$. For the public sector, the estimates were $£ 505$ for ASHE and $£ 462$ for AWE.

\section{Low pay jobs}

In April 2010 the number of UK jobs paid below the national minimum wage was 271,000, accounting for 1.1 per cent of all jobs in the labour market.

There were three rates for the national minimum wage in April 2010: one for those aged between 16 and 17 (£3.57 per hour), one for those aged between 18 and 21 ( $£ 4.83$ per hour) and one for those aged 22 and over (£5.80 per hour).

The number of jobs paid below the national minimum wage was:

- 15,000 jobs (5.4 per cent) held by those aged 16 to 17

- 48,000 jobs (2.9 per cent) held by those aged 18 to 21

- 207,000 jobs ( 0.9 per cent) held by those aged 22 and over

People in part-time work were more than twice as likely as people in full-time work to be paid less than the minimum wage, with 1.8 per cent of part-time jobs and 0.8 per cent of full-time jobs falling below the minimum wage. Jobs held by women are more likely to fall below the minimum wage than jobs held by men (1.2 per cent compared with 0.9 per cent). This is primarily due to the greater number of women in part-time jobs.

It is important to note that these estimates do not measure non-compliance with the National Minimum Wage legislation. ASHE does not indicate whether individuals fall into a category that is exempt from the legislation, such as apprentices or new trainees.

\section{Further information}

Tables accompanying (and referenced within) this article are available at www.statistics.gov.uk/StatBase/Product.asp?vlnk=14123

\section{Notes}

1. The 2005 ASHE questionnaire introduced a change in the make-up of gross weekly earnings relating to payments by results/incentive payments. For comparability, this change was also 
applied to the 2004 results. ASHE results for 2004 to 2010 include incentive payments paid and earned in the pay period, but exclude payments made less often than every pay period. As a result of this change in definition, estimates for payments by results in the pay period are understated from 2004 onwards as incentive payments made in a later pay period than the pay period in which the work is carried out are not captured. However, the estimates are improved relative to previous years, when estimates were overstated due to the capture of some annual incentive payments in monthly or weekly pay periods. The new definition results in greater consistency due to the fact that the data reported do not depend on the reference date of the questionnaire or when annual bonuses are paid, as in previous years.

2. Millard B and Machin A (2007) 'Characteristics of public sector workers', Economic \& Labour Market Review, Volume 1 Number 5, pp 46-55

\section{Contact}

Earnings helpdesk,

Room 1.264,

Office for National Statistics,

Cardiff Road,

Newport NP10 8XG.

e-mail: earnings@ons.gov.uk

Tel: 01633456120 


\section{Technical Note: Survey details}

The Annual Survey of Hours and Earnings (ASHE) is based on a sample of employee jobs taken from HM Revenue \& Customs PAYE records. Information on earnings and paid hours is obtained in confidence from employers. It does not cover the self-employed nor does it cover employees not paid during the reference period. In 2010 the information related to the pay period which included 21 April. The 2010 ASHE is based on approximately 181 thousand returns.

ASHE replaced the New Earnings Survey (NES) as ONS's main source of information on the distribution of earnings. Articles describing the ASHE methodology and the impact of its introduction on 1997 to 2004 data are available on the National Statistics website at www.statistics.gov.uk/StatBase/Product.asp?vlnk=13101. The main differences between ASHE and NES are:

- ASHE results are weighted to the number of jobs given by the Labour Force Survey

- ASHE imputes for item non-response

- The coverage of employees for ASHE is greater than that of NES

- The median replaces the mean as the headline statistic. The median is the value below which 50 per cent of employees fall. It is preferred over the mean for earnings data as it is less influenced by extreme values and because of the skewed distribution of earnings

\section{Changes in 2004}

Since 2004, supplementary survey information has been collected to improve coverage and make the survey more representative. This includes employees who have either changed or started new jobs between sample selection from HM Revenue \& Customs records and the survey reference period in April. 2004 results are also available excluding the supplementary information so as to be comparable with the back-series for 1997 to 2003, which was generated by imputing and weighting data from the New Earnings Survey (NES).

\section{Changes in 2005}

A new questionnaire was introduced for the 2005 survey. This questionnaire brought significant improvement to the quality of the results. More details on the impact of introducing the new questionnaire can be found at www.statistics.gov.uk/cci/article.asp?id=1294

Changes to the wording and definitions meant that some of the information requested from respondents differed from that supplied in previous surveys. The introduction of the pay 'for other reasons' question resulted in the inclusion of earnings information which may not have been collected in the past. Results for 2004 including supplementary information were reworked to allow for this missing pay. For more details on the methodology involved in estimating pay for other reasons see the National Statistics website at www.statistics.gov.uk/cci/article.asp?id=1299

In addition, the definition of incentive/bonus pay changed for 2005 to only include payments that were paid and earned in April. This brought the definition more in line with that used in the Average Earnings Index (AEI) and resulted in greater consistency of ASHE results. Results for 2004 
including supplementary information were reworked to exclude irregular bonus/incentive payments to make them consistent with results from 2005 onwards. The adjustments made to the 2004 data in order to produce estimates comparable with the 2005 data also had an impact on the gap between public and private sector earnings. The changes on the questionnaire were the exclusion of incentive payments paid outside the pay period and the inclusion of pay for other reasons. The exclusion of incentive payments paid outside the pay period pulls down the private sector estimates more than the public sector estimates because private sector employees receive a higher proportion of incentive pay than public sector employees. Also, public sector employees receive greater proportions of pay for other reasons. Therefore, public sector estimates increased more than the private sector estimates when other pay was included.

\section{Changes in 2006}

In 2006 ASHE moved to the ONS standard for geographic areas using Output Areas (OAs) as the building block to higher level geographic breakdowns. Previously, ASHE geographies were created by matching returned postcode information against the Inter Departmental Business Register to give various levels of geographic information. The key points are:

- ASHE results for geographic areas are produced in line with the ONS standard and this allows further geographic analysis variables to be produced

- The quality of geographic results has improved

In addition, from 2006 the Labour Force Survey (LFS) moved from using seasonal quarters to calendar quarters. As ASHE uses LFS data in the calculation of aggregation weights, it was necessary to move from using data taken from the LFS spring quarter to LFS quarter two.

The inclusion of supplementary information since 2004, the introduction of a new questionnaire in 2005, and the move to using new ONS geographies and LFS calendar quarters in 2006 has meant that the ASHE results are discontinuous in 2004. Therefore a consistent series which takes into account all of these changes has been produced going back to 2004. For 2004, results are also available that exclude supplementary information so as to allow comparisons with the back series generated by imputation and weighting of the 1997 to 2003 NES data.

\section{Changes in 2007}

In March 2007 ONS released information on its statistical work priorities over the period 2007-08. ONS announced that the sample size of the ASHE was to be reduced by 20 per cent. ASHE results for 2007 and 2008 are based on approximately 145 thousand returns, down from 175,000 in 2006 . The impact of this change was minimised by reducing the sample in an optimal way, with the largest sample reductions occurring in industries where earnings are least variable. The sample cut did not affect Northern Ireland, neither did it affect a number of organisations with an agreement to provide information electronically. 
ONS also introduced a small number of methodological changes, which improved the quality of the results. These included changes to the sample design itself, as well as the introduction of an automatic occupation coding tool, ACTR.

The key benefits of moving to ACTR coding are:

- An improvement in the quality and consistency of ASHE results

- Out-of-date codes are updated annually

- ACTR provides ASHE and ONS with a standard tool for coding occupation

The methodological changes made in 2007 have been applied to the 2006 ASHE so that from 2006 to 2010 results are available on the same basis. For 2006, results are also available on a continuous basis with 2004 and 2005.

Further information can be found on the National Statistics website at www.statistics.gov.uk/downloads/theme_labour/ASHE/ChangelnASHE07.pdf

\section{Changes in 2008}

In May 2008 the LFS was re-weighted to the latest (2007/08) population estimates. Previously LFS results were based on population totals published in 2003. ASHE uses LFS to calculate aggregation weights. The revised LFS figures were used for 2007 (revised) and 2008 ASHE results. The impact of the new weights on the ASHE results for 2007 is small.

\section{Changes in 2009}

In 2009 the 1 per cent sample of employees whose employers had registered PAYE schemes was restored, following the two years in which the sample size was reduced by 20 per cent. ASHE results for 2009 were based on approximately 179,000 returns, up from 146,000 returns in 2008 .

The Standard Industrial Classification (SIC) 2007 replaced SIC 2003 as the classification used to present earnings statistics for ASHE. The first year available on the new basis is 2008. From 2009 onwards the figures are presented on the SIC 2007 basis only.

It is also important to note that ASHE includes breakdowns by public and private sector according to the legal status of the employers. Between 2008 and 2009 Lloyds Banking Group, the Royal Bank of Scotland Group and HBOS PLC were reclassified from the private sector to the public sector. Interpretation of public / private sector movements is therefore more difficult between 2008 and 2009 than in previous years. 


\section{Changes in 2010}

In 2010 the system underpinning the ASHE sample, HM Revenue and Customs' PAYE system, was replaced. Where the previous system represented employers' accounts, the new system reflects the PAYE pay and tax details of individuals. The introduction of this new PAYE system resulted in a discontinuity in the way that employments are created and recorded. The change had a minimal impact on the ASHE sample and the results for 2010. Information about the steps taken to produce and quality-assure the 2010 sample and results is available at www.statistics.gov.uk/downloads/theme_labour/ashe/hmrc-impact-ashe2010.pdf

The change in the survey's sampling frame has extended the coverage of ASHE to all levels of earnings, and this extension should improve the quality of the estimates going forward.

\section{Definitions}

The earnings information collected relates to gross pay before tax, National Insurance or other deductions, and generally excludes payments in kind. With the exception of annual earnings, the results are restricted to earnings relating to the survey pay period and so exclude payments of arrears from another period made during the survey period. Payments due as a result of a pay settlement but not yet paid at the time of the survey are also excluded.

For particular groups of employees, changes in median earnings between successive surveys may be affected by changes in the timing of pay settlements, in some cases reflecting more than one settlement and in other cases no settlement at all.

Most of the published ASHE analyses relate to full-time employees on adult rates whose earnings for the survey pay period were not affected by absence. They do not include the earnings of those who did not work a full week, and those whose earnings were reduced because of sickness, shorttime working, etc. Also, they do not include the earnings of employees not on adult rates of pay, most of whom will be young people. Some more information on the earnings of young people and part-time employees is available in the detailed annual published ASHE results. Full-time employees are defined as those who work more than 30 paid hours per week or those in teaching professions who work more than 25 paid hours per week.

\section{Factors contributing to earnings growth}

The increase in average earnings from one year to the next reflects several factors: pay settlements implemented between the April survey dates; changes in the amount of paid overtime and other payments relative to basic pay; and the structural effects of changes in the composition of the ASHE sample and the employed labour force. 


\section{Revisions}

In line with normal practice this article contains revised estimates from the 2009 survey results published on 12th November 2009. These take account of some corrections to the original 2009 data which were identified during the validation of the results for 2010 , as well as late returns.

\section{Other earnings information}

The Average Weekly Earnings (AWE) is based on the Monthly Wages and Salaries Survey of 9,000 employers and provides information on changes in mean earnings for broad industrial sectors. No information is available on occupation, paid hours worked, and other characteristics of the workforce.

The LFS collects information on the earnings and hours of about 15,000 households over each quarter. In addition it collects data on a wide range of personal characteristics, including education level and origin. This enables the preparation of statistics on levels and distribution of earnings similar to ASHE but with lower precision due to the much smaller sample size.

\section{Publication arrangements}

National averages of earnings hide wide variations between different collective agreements, industries, occupations, regions and age groups. The published tables containing the detailed annual ASHE results for the UK include analyses of each of these and are available on the National Statistics website at www.statistics.gov.uk/StatBase/Product.asp?vlnk=13101

Low pay estimates show the number of jobs paid below the National Minimum Wage in the UK. The estimates are produced using a methodology based solely on ASHE. Further information on the low pay methodology and detailed results are available at www.statistics.gov.uk/StatBase/Product.asp?vlnk=5837 